\title{
MENINGKATKAN KOMPETENSI PROFESIONAL GURU DENGAN MENERAPAN PENDEKATAN SUPERVISI KOLABORATIF DI SDN 14 PULAU KUMBANG
}

\author{
Amran \\ Kepala SN Negeri 14 Pulau Kumbang \\ Email : amransdn14pulaukumbang@gmail.com
}

\begin{abstract}
Abstrak
Faktor eksternal yang diduga mengakibatkan rendahnya kompetensi profesional guru adalah pelaksanaan supervisi oleh kepala sekolah yang lebih bersifat menilai. Idealnya, supervisi dilaksanakan secara kolegial, tidak menggurui, bersifat kemitraan dan pendampingan, serta dilakukan melalui diskusi dan curah pendapat secara terbuka dan fleksibel untuk membantu guru merefleksi kinerjanya dalam melaksanakan tugas profesionalnya. Salah satu pendekatan yang mengedepankan kemitraan atau rekan kerja antara kepala sekolah sebagai supervisor akademik dan guru sebagai orang yang disupervisi, lebih bersifat mendampingi melalui diskusi dan curah pendapat secara terbuka dan fleksibel serta memiliki tujuan yang jelas untuk membantu guru berkembang menjadi tenaga-tenaga profesional melalui kegiatan-kegiatan reflektif adalah pendekatan supervisi kolaboratif. Berdasarkan latar belakang masalah di atas, untuk mengatasi masalah rendahnya kompetensi profesional guru dalam melaksanakan tugas profesionalnya, maka diterapkan tindakan berupa pendekatan supervisi yang belum pernah dilakukan sebelumnya yaitu pendekatan supervisi kolaboratif. Tindakan tersebut selanjutnya diteliti melalui penelitian tindakan sekolah yang berjudul "Penerapan Pendekatan Supervisi Kolaboratif untuk Meningkatkan Kompetensi Profesional Guru di SDN 14 Pulau Kumbang”. Peningkatan kompetensi profesional guru di SDN 14 Pulau Kumbang dari pra-siklus ke siklus 1 sebesar 18,18 poin. Rata-rata kompetensi profesional guru pada pra-siklus sebesar 52,27 dengan kriteria kurang dan pada siklus 1 sebesar 70,45 dengan kriteria cukup. Kompetensi profesional guru juga mengalami peningkatan dari siklus 1 ke siklus 2 sebesar 18,19 poin. Rata-rata kompetensi profesional guru pada siklus 2 sebesar 88,64 dengan kriteria baik. Jadi, dapat disimpulkan bahwa kompetensi profesional guru di SDN 14 Pulau Kumbang dapat ditingkatkan melalui penerapan pendekatan supervisi kolaboratif
\end{abstract}

\section{Kata Kunci : Kompetensi, Profesional Guru, Supervisi Kolaboratif}

\section{PENDAHULUAN}

Guru merupakan ujung tombak keberhasilan pendidikan. Profesionalisme seorang guru terlihat dari kompetensinya sebagai seorang guru yang terdiri dari kompetensi pedagogik, profesional, keperibadian dan sosial. Salah satu dimensi kompetensi guru sesuai dengan Peraturan Menteri Pendidikan Nasional Republik Indonesia Nomor 16 Tahun 2007 tentang Standar Kualifikasi Akademik dan Kompetensi Guru adalah kompetensi profesional. Dengan Permendiknas tersebut berarti seorang guru harus kompeten dalam melakukan kinerja profesionalnya. Kompetensi profesional guru menurut Permendiknas Nomor 16 Tahun 2007 terdiri dari kemampuan guru dalam: (1) menguasai materi, struktur, konsep, dan pola pikir keilmuan yang mendukung mata pelajaran yang diampu; (2) menguasai standar kompetensi dan kompetensi dasar mata pelajaran/ bidang pengembangan yang diampu; (3) mengembangkan materi pembelajaran yang diampu secara kreatif; (4) mengembangkan keprofesionalan secara berkelanjutan dengan melakukan tindakan reflektif; dan (5) memanfaatkan teknologi informasi dan komunikasi untuk berkomunikasi dan mengembangkan diri.

Berdasarkan hasil refleksi diri yang telah dilakukan oleh peneliti sebagai kepala sekolah, selama ini kepala sekolah melaksanakan tugas supervisi akademiknya dengan menerapkan pendekatan supervisi langsung secara individual, dengan cara mendatangi guru yang sedang bertugas, mengamati kinerjanya dan melakukan penilaian. Pendekatan supervisi individual ini tidak terlalu efektif untuk meningkatkan kompetensi guru dalam melaksanakan tugasnya khususnya yang berkaitan dengan kompetensi profesionalnya. Hasil kajian empirik yang peneliti lakukan terhadap guru-guru di SDN 14 Pulau Kumbang menunjukkan bahwa kompetensi profesional guru masih rendah terutama pada kompetensi guru dalam mengembangkan materi pembelajaran yang diampu secara kreatif. Rata-rata kemampuan guru dalam mengembangkan materi pembelajaran yang diampunya berdasarkan penilaian kinerja guru terhadap 22 orang guru di SDN 14 Pulau Kumbang, diperoleh data sebagai berikut: 


\begin{tabular}{|c|c|c|c|c|}
\hline el & 1. & $\begin{array}{l}\text { Kompetensi } \\
\text { Mengembangka } \\
\text { Pembelajaran }\end{array}$ & & $\begin{array}{l}\text { dalam } \\
\text { Materi }\end{array}$ \\
\hline \multirow[b]{2}{*}{ No. } & \multirow{2}{*}{\multicolumn{2}{|c|}{ Aspek }} & \multicolumn{2}{|c|}{ Rata-rata } \\
\hline & & & $\begin{array}{c}\text { Skala } \\
4\end{array}$ & $\begin{array}{c}\text { Skala } \\
100\end{array}$ \\
\hline A. & \multicolumn{2}{|c|}{ Keterurutan } & 2,14 & 53,41 \\
\hline B. & \multicolumn{2}{|c|}{ Keberjenjangan } & 2,27 & 56,82 \\
\hline C. & \multicolumn{2}{|c|}{ Kedalaman } & 1,77 & 44,32 \\
\hline D. & \multicolumn{2}{|c|}{ Keluasan } & 2,18 & 54,55 \\
\hline $\mathrm{Ni}$ & \multicolumn{2}{|c|}{ ai Rata-rata Keseluruhan } & 2,09 & 52,27 \\
\hline
\end{tabular}

Hasil analisis data pada tabel di atas menunjukkan bahwa kompetensi guru dalam mengembangkan materi pembelajaran yang diampu masih pada kategori sedang yaitu indeks rata-rata 2,09 atau 52,27. Hasil refleksi terhadap temuan tersebut menunjukkan bahwa faktor yang menyebabkan masih rendahnya kompetensi guru tersebut diduga disebabkan oleh faktor internal dan eksternal. Faktor internal yang diduga mempengaruhi rendahya kompetensi profesional guru antara lain: (1) Guru belum memahami teknik pengembangan materi pembelajaran; (2) Guru tidak melakukan analisis materi pembelajaran sebelum mengembangkan bahan ajar atau materi pembelajaran; dan (3) Kurangnya motivasi diri guru untuk melakukan kinerja profesionalnya dengan baik.

Faktor eksternal yang diduga mengakibatkan rendahnya kompetensi profesional guru adalah pelaksanaan supervisi oleh kepala sekolah yang lebih bersifat menilai. Idealnya, supervisi dilaksanakan secara kolegial, tidak menggurui, bersifat kemitraan dan pendampingan, serta dilakukan melalui diskusi dan curah pendapat secara terbuka dan fleksibel untuk membantu guru merefleksi kinerjanya dalam melaksanakan tugas profesionalnya. Salah satu pendekatan yang mengedepankan kemitraan atau rekan kerja antara kepala sekolah sebagai supervisor akademik dan guru sebagai orang yang disupervisi, lebih bersifat mendampingi melalui diskusi dan curah pendapat secara terbuka dan fleksibel serta memiliki tujuan yang jelas untuk membantu guru berkembang menjadi tenaga-tenaga profesional melalui kegiatan-kegiatan reflektif adalah pendekatan supervisi kolaboratif.

Berdasarkan latar belakang masalah di atas, untuk mengatasi masalah rendahnya kompetensi profesional guru dalam melaksanakan tugas profesionalnya, maka diterapkan tindakan berupa pendekatan supervisi yang belum pernah dilakukan sebelumnya yaitu pendekatan supervisi kolaboratif. Tindakan tersebut selanjutnya diteliti melalui penelitian tindakan sekolah yang berjudul
"Penerapan Pendekatan Supervisi Kolaboratif untuk Meningkatkan Kompetensi Profesional Guru di SDN 14 Pulau Kumbang".

Berdasarkan latar belakang di atas, masalah penelitian dapat dirumuskan sebagai berikut : (1) Bagaimanakah perkembangan proses supervisi kolaboratif untuk meningkatkan kompetensi profesional guru di SDN 14 Pulau Kumbang? (2) Bagaimanakah peningkatan kompetensi profesional guru di SDN 14 Pulau Kumbang setelah diterapkan pendekatan supervisi kolaboratif?

Untuk mengatasi masalah rendahnya kompetensi profesional guru di SDN 14 Pulau Kumbang, selanjutnya dilakukan tindakan berupa penerapan pendekatan supervisi kolaboratif. Pendekatan supervisi kolaboratif merupakan salah satu pendekatan supervisi yang dapat digunakan oleh kepala sekolah secara kolegial, bersifat mendampingi dan kemitraan dalam membimbing/ memfasilitasi guru agar dapat melaksanakan tugas profesionalnya. Karakteristik pendekatan supervisi kolaboratif dalam pembimbingan terhadap guru menempatkan kepala sekolah sebagai rekan kerja, kedua belah pihak berbagi kepakaran, curah pendapat, diskusi, presentasi dilaksanakan dengan terbuka dan fleksibel serta memiliki tujuan yang jelas, membantu guru berkembang menjadi tenagatenaga professional melalui kegiatan-kegiatan reflektif. Dengan demikian, penerapan pendekatan supervisi kolaboratif ini diharapkan dapat meningkatkan kompetensi guru di SDN 14 Pulau Kumbang khususnya kompetensi profesional.

Tujuan penelitian tindakan sekolah yang telah dilaksanakan ini adalah untuk mendeskripsikan: (1) perkembangan proses supervisi kolaboratif untuk meningkatkan kompetensi profesional guru di SDN 14 Pulau Kumbang. (2) peningkatan kompetensi profesional guru di SDN 14 Pulau Kumbang setelah diterapkan pendekatan supervisi kolaboratif.

Hasil penelitian ini diharapkan bermanfaat bagi kepala sekolah, guru, sekolah dan dinas pendidikan sebagai berikut: (1) Menjadi rujukan untuk menerapkan pendekatan supervisi kolaboratif dapat dijadikan sebagai alternatif pendekatan supervisi untuk meningkatkan kompetensi guru. (2) Memberikan gambaran tentang kompetensi profesional guru setelah diterapkan pendekatan supervisi kolaboratif untuk selanjutnya dijadikan sebagai bahan untuk merumuskan tindak lanjut kegiatan supervisi. (3) Meningkatkan kompetensi profesional guru (4) Memberikan gambaran tentang kompetensi dirinya sebagai guru khususnya pada aspek kompetensi profesional untuk selanjutnya dijadikan bahan refleksi untuk meningkatkan kinerjanya. (5) 
Meningkatnya kualitas sekolah sebagai dampak meningkatnya kualitas kerja guru dalam melaksanakan tugas profesionalnya. (6) Dapat dijadikan rujukan dalam menentukan kebijakan untuk memberikan dukungan penuh secara simultan dan berkelanjutan dalam meningkatkan kinerja guru. Hasil PTS ini pun dijadikan bahan untuk melakukan perbaikan dan peningkatan mutu kinerja sekolah.

Supervisor adalah seorang yang profesional. Dalam menjalankan tugasnya, ia bertindak atas dasar kaidah-kaidah ilmiah untuk meningkatkan mutu pendidikan. Untuk melakukan supervisi diperlukan kelebihan yang dapat melihat dengan tajam terhadap permasalahan peningkatan mutu pendidikan, menggunakan kepekaan untuk memahaminya dan tidak hanya sekedar menggunakan penglihatan mata biasa. Ia membina peningkatan mutu akademik melalui penciptaan situasi belajar yang lebih baik, baik dalam hal fisik maupun lingkungan nonfisik.

Pendekatan supervisi kolaboratif dilaksanakan oleh supervisor dengan berbagi tanggung jawab dengan orang yang disupervisi. Dengan demikian, pada saat kepala sekolah melaksanakan supervisi kolaboratif, maka kepala sekolah berbagi tanggung jawab dengan guru. Tugas supervisi oleh kepala sekolah dalam supervisi kolaboratif adalah mendengarkan dan memperhatikan secara cermat keluhan guru terhadap masalah perbaikan, peningkatan, dan pengembangan kinerjanya. Dalam pendekatan supervisi kolaboratif, kepala sekolah dapat meminta penjelasan guru terhadap hal-hal yang kurang dipahaminya. Selanjutnya, kepala sekolah mendorong guru untuk mengaktualisasikan pemikiran bersama dalam praktik nyata pemecahan masalah yang berkaitan dengan tugas guru (Glickman, 1984).

Penilaian unjuk kerja guru dalam mengelola proses pembelajaran sebagai suatu proses pemberian estimasi kualitas unjuk kerja guru dalam mengelola proses pembelajaran, merupakan bagian integral dari serangkaian kegiatan supervisi akademik. Apabila dikatakan bahwa supervisi akademik merupakan serangkaian kegiatan membantu guru mengembangkan kemampuannya, maka dalam pelaksanaannya terlebih dahulu perlu diadakan penilaian kemampuan guru, sehingga bisa ditetapkan aspek yang perlu dikembangkan dan cara mengembangkannya.

Alfonso, Firth, dan Neville (1981) menegaskan " Instructional supervision is here in defined as: behavior officially designed by the organization that directly affects teacher behavior in such a way to facilitate pupil learning and achieve the goals of organization". Menurut mereka, terdapat tiga kunci pokok dalam pengertian supervisi akademik. (1) Supervisi akademik harus secara langsung mempengaruhi dan mengembangkan perilaku guru dalam mengelola proses pembelajaran. Inilah karakteristik esensial supervisi akademik. Sehubungan dengan ini, janganlah diasumsikan secara sempit, bahwa hanya ada satu cara terbaik yang bisa diaplikasikan dalam semua kegiatan pengembangan perilaku guru. Tidak ada satupun perilaku supervisi akademik yang baik dan cocok bagi semua guru (Glickman, 1981). Tegasnya, tingkat kemampuan, kebutuhan, minat, dan kematangan profesional serta karakteristik personal guru lainnya harus dijadikan dasar pertimbangan dalam mengembangkan dan mengimplementasikan program supervisi akademik (Sergiovanni, 1987 dan Daresh, 1989). (2) Perilaku supervisor dalam membantu guru mengembangkan kemampuannya harus didesain secara ofisial, sehingga jelas waktu mulai dan berakhirnya program pengembangan tersebut. Desain tersebut terwujud dalam bentuk program supervisi akademik yang mengarah pada tujuan tertentu. Oleh karena supervisi akademik merupakan tanggung jawab bersama antara supervisor dan guru, maka alangkah baiknya jika programnya didesain bersama oleh supervisor dan guru. (3) Tujuan akhir supervisi akademik adalah agar guru semakin mampu memfasilitasi siswa dalam pembelajaran.

Tujuan supervisi akademik adalah membantu guru mengembangkan kemampuannya mencapai tujuan pembelajaran yang telah dicanangkan bagi siswanya (Glickman, 1981). Melalui supervisi akademik diharapkan kualitas akademik yang dilakukan oleh guru semakin meningkat (Neagley, 1980). Pengembangan kemampuan dalam konteks ini janganlah ditafsirkan secara sempit, sematamata ditekankan pada peningkatan pengetahuan dan keterampilan mengajar guru, melainkan juga pada peningkatan komitmen (commitmen) atau kemauan (willingness) atau motivasi (motivation) guru, sebab dengan meningkatkan kemampuan dan motivasi kerja guru, kualitas pembelajaran akan meningkat. Sedangkang menurut Sergiovanni (1987) ada tiga tujuan supervisi akademik sebagaimana dapat dilihat pada Gambar 2.1. 


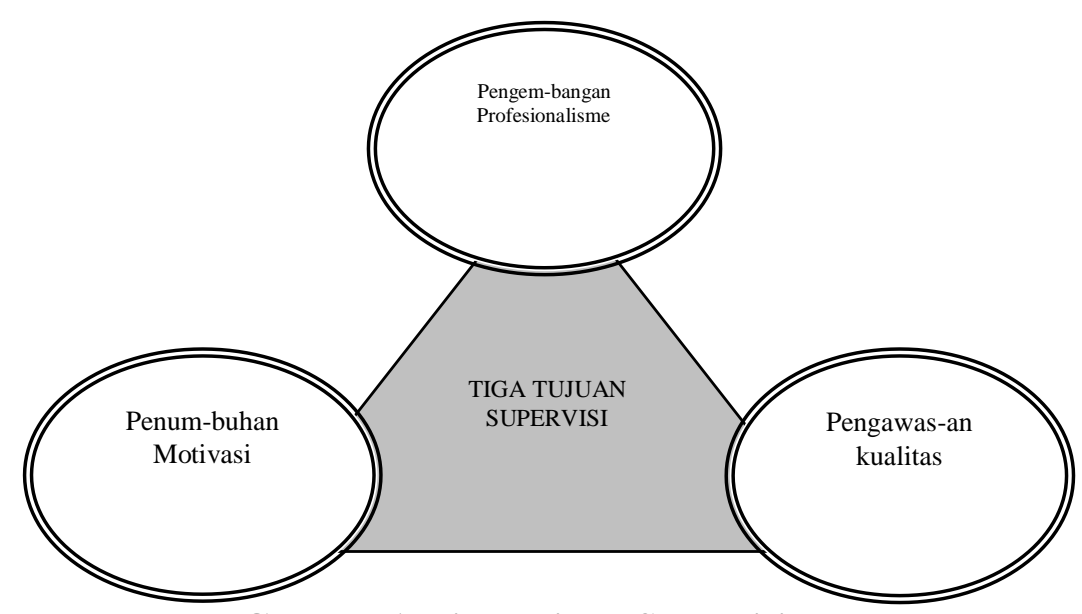

Gambar 1. Tiga Tujuan Supervisi

Supervisi akademik diselenggarakan dengan maksud membantu guru mengembangkan kemampuan profesionalnnya dalam memahami kegiatan akademik, kehidupan kelas, mengembangkan keterampilan mengajarnya dan menggunakan kemampuannya melalui teknikteknik tertentu. Supervisi akademik diselenggarakan dengan maksud untuk memonitor kegiatan belajar mengajar di sekolah. Kegiatan memonitor ini bisa dilakukan melalui kunjungan kepala sekolah ke kelas di saat guru sedang mengajar, percakapan pribadi dengan guru, teman sejawatnya, maupun dengan sebagian siswanya. Supervisi akademik diselenggarakan untuk mendorong guru menerapkan kemampuannya dalam melaksanakan tugas-tugas mengajarnya, mendorong guru mengembangkan kemampuannya sendiri, serta mendorong guru agar ia memiliki perhatian yang sungguh-sungguh (commitment) terhadap tugas dan tanggung jawabnya.

\section{METODOLOGI PENELITIAN}

Metode penelitian yang digunakan pada penelitian ini adalah metode Penelitian Tindakan Sekolah (PTS) dengan model Kemmis dan Mc. Taggart yang merupakan model pengembangan dari model Kurt Lewin. Dikatakan demikian, karena di dalam suatu siklus terdiri atas empat komponen, keempat komponen tersebut, meliputi: (1) perencanaan, (2) aksi/ tindakan, (3) observasi, dan (4) refleksi. Setelah suatu siklus selesai diimplementasikan, khususnya sesudah adanya refleksi, kemudian diikuti dengan adanya perencanaan ulang yang dilaksanakan dalam bentuk siklus tersendiri.

Penelitian ini dilakukan di SDN 14 Pulau Kumbang yang memiliki karakteristik bahwa di sekolah ini kepala sekolah selalu melakukan supervisi akademik secara individual, tidak secara kolaboratif padahal karakteristik guru di sekolah ini adalah dapat bekerja secara kolaboratif dan memiliki motivasi untuk selalu merefleksi kinerjanya dan berbagi pengalaman dengan rekan sejawatnya.

Dalam penelitian ini yang menjadi subyek penelitian adalah 8 gurudi SDN 14 Pulau Kumbang yang memiliki karakteristik bahwa kompetensi profesionalnya rendah khususnya dalam mengembangkan materi pembelajaran. Namun, guru di sekolah ini dapat bekerja secara kolaboratif dan memiliki motivasi untuk selalu merefleksi kinerjanya serta berbagi pengalaman dengan rekan sejawatnya.

Jadwal pelaksanaan penelitian tindakan sekolah dengan menerapkan pendekatan supervisi kolaboratif untuk meningkatkan kompetensi profesional guru telah dikoordinasikan dan disepakati bersama 8 guruyaitu pada bulan September s.d. Desember 2019 (4 bulan).

Faktor-faktor yang diteliti dalam PTS ini adalah proses supervisi kolaboratif yang terkait dengan keterlaksanaan prinsip-prinsip supervisi kolaboratif yaitu prinsip kolaboratif, kolegial, kemitraan, terbuka dan fleksibel pada ketiga tahapan supervisi kolaboratif yang terdiri dari tahap pra-supervisi kolaboratif, supervisi kolaboratif dan pasca-supervisi kolaboratif. Selain hal tersebut, faktor lain yang diteliti adalah kompetensi profesional guru dalam mengembangkan materi pembelajaran.

Alat pengumpul data yang digunakan untuk mengumpulkan data yang berkaitan dengan variabel yang diteliti adalah: (1) Lembar observasi terdiri dari lembar observasi proses supervisi kolaboratif dan lembar observasi kinerja guru dalam melaksanakan kinerja profesionalnya dalam mengembangkan materi pembelajaran. Lembar observasi proses supervisi kolaboratif digunakan untuk mengamati aktivitas kepala sekolah dan guru dalam melakukan proses supervisi dengan 
menerapkan pendekatan supervisi kolaboratif. Lembar observasi kinerja profesional guru digunakan untuk mengamati kinerja guru dalam mengembangkan materi pembelajaran. (2) Catatan lapangan digunakan oleh peneliti untuk mencatat temuan-temuan lain yang tidak terdapat pada lembar observasi terkait dengan aktivitas kepala sekolah dan guru selama supervisi dengan menerapkan pendekatan kolaboratif. (3) Pedoman wawancara digunakan ketika wawancara dilakukan oleh kepala sekolah terhadap 8 gurutentang masalah-masalah yang urgen untuk dipecahkan bersama terkait kinerja profesionalnya dalam mengembangkan materi pembelajaran.

Teknik pengolahan dan analisis data dilakukan secara kuantitatif dan kualitatif. Teknik pengolahan data secara kuantitatif dilakukan terhadap variabel kompetensi profesional guru. Data yang diperoleh dari hasil pengamatan atau observasi kinerja profesional guru dalam mengembangkan materi pembelajaran yang terdiri dari empat aspek yaitu keterurutan, keberjenjangan, kedalaman, dan keluasan diolah dengan menentukan nilai rata-ratanya. Analisis data kompetensi profesional guru dilakukan menggunakan prosentase (\%), yakni perhitungan yang digunakan untuk mengetahui tingkat prosentase skor penilaian dari masing-masing indikator kompetensi profesional guru dalam mengembangkan materi pembelajaran. Data kuantitatif berupa prosentase tersebut kemudian dijadikan dasar untuk dikonversi kedalam data kualitatif menggunakan kriteria berikut.

Tabel 2. Kriteria Kompetensi Profesional Guru

\begin{tabular}{cc}
\hline Skor & Kriteria \\
\hline $91-100$ & Sangat Baik \\
\hline $76-90$ & Baik \\
\hline $61-75$ & Cukup \\
\hline $51-60$ & Kurang \\
\hline$\leq 50$ & Sangat Kurang \\
\hline
\end{tabular}

Teknik pengolahan data kualitatif dilakukan terhadap variabel proses supervisi kolaboratif yang dikumpulkan melalui lembar observasi proses supervisi kolaboratif yang diolah dengan cara mengkategorikan dan mengklasifikasikan data berdasarkan analisis kaitan logis, kemudian ditafsirkan dalam konteks permasalahan penelitian. Kegiatan ini berupaya memunculkan makna dari setiap data yang didapat, sehingga data itu tidak hanya bersifat deskriptif. Dalam penelitian dengan pendekatan kualitatif, pengolahan dan analisis data dilakukan secara terus-menerus dari awal sampai akhir pelaksanaan program tindakan.
Berikut prosedur penelitian yang telah dilaksanakan: Siklus 1 : (1) Perencanaan : (a) Merencanakan proses supervisi kolaboratif sesuai dengan prinsip-prinsip pendekatan supervisi kolaboratif. (2) Menyusun instrumen penelitian berupa lembar observasi proses supervisi kolaboratif, lember observasi kinerja profesional guru dalam mengembangkan materi pembelajaran, panduan wawancara dan catatan lapangan. (30 Melakukan analisis kebutuhan guru. (4) Sesuai jadwal, peneliti memberikan materi tentang teknis pengembangan materi pembelajaran dan bahan ajar. (5) Menyepakati jadwal kegiatan pada pertemuan berikutnya. (2) Pelaksanaan Tindakan: (a) Melaksanakan diskusi dan curah pendapat antara kepala sekolah dengan 8 gurutentang masalah-masalah krusial pada saat mengembangkan materi pembelajaran dan bahan ajar. (b) Melaksanakan tindakan berupa supervisi kolaboratif antara kepala sekolah dan guru dengan melaksanakan kelima prinsip pendekatan supervisi kolaboratif yaitu prinsip kolaboratif, kolegial, kemitraan, terbuka dan fleksibel. (c) Melaksanakan refleksi bersama antara kepala sekolah dan 8 gurutentang pelaksanaan kinerja profesionalnya pada kelompok kerja guru difasilitasi oleh kepala sekolah. (3) Observasi. Observasi dilaksanakan oleh kepala sekolah terhadap proses supervisi kolaboratif yang sedang dilaksanakan dan kinerja profesional guru dalam mengembangkan materi pembelajaran dan bahan ajar dan mencatat semua temuannya pada instrumen yang telah disediakan. Berikut adalah fokus-fokus dari kegiatan observasi: (a) Proses supervisi kolaboratif yang terdiri dari pelaksanaan kelima prinsip pendekatan supervisi kolaboratif yaitu prinsip kolaboratif, kolegial, kemitraan, terbuka dan fleksibel. (b) Kompetensi profesional guru dalam mengembangkan materi pembelajaran dan bahan ajar. (4) Tahap Analisis dan Refleksi.

\section{HASIL DAN PEMBAHASAN PENELITIAN}

Penelitian tindakan sekolah ini dilakukan dalam dua siklus. Berikut merupakan deskripsi hasil penelitian tindakan sekolah terkait dengan proses supervisi dengan menerapkan pendekatan supervisi kolaboratif pada siklus 1 dan 2.

Supervisi kolaboratif pada siklus 1 ini dilaksanakan pada tanggal 3 September s.d. 3 November 2019. Pendekatan supervisi kolaboratif pada siklus 1 dilaksanakan dengan menerapkan kesepuluh prinsip pendekatan supervisi kolaboratif yaitu prinsip kolaboratif, kolegial, kemitraan, terbuka dan fleksibel melalui tahapan-tahapan spesifik sebagai berikut: (1) Tahap pra-supervisi kolaboratif, kepala sekolah bersama 8 gurumelaksanakan curah pendapat dan diskusi di 
sekolah difasilitasi oleh kepala sekolah tentang masalah-masalah krusial guru dalam mengembangkan materi pembelajaran dan bahan ajar. (2) Tahap supervisi kolaboratif, kepala sekolah melaksanakan supervisi kolaboratif bersama guru pada saat guru sedang melaksanakan kinerja profesionalnya dengan menerapkan kelima prinsip pendekatan supervisi kolaboratif yaitu prinsip kolaboratif, kolegial, kemitraan, terbuka dan fleksibel. (3) Tahap pasca-supervisi kolaboratif, kepala sekolah bersama 8 gurumelaksanakan refleksi pelaksanaan kinerja profesionalnya difasilitasi oleh kepala sekolah.
Temuan-temuan selama proses supervisi kolaboratif berlangsung dikumpulkan menggunakan lembar observasi proses supervisi kolaboratif dan catatan lapangan. Peneliti sebagai observer mengamati keterlaksanaan supervisi dengan menerapkan pendekatan supervisi kolaboratif yang selanjutnya memberikan deskripsi pada kolom yang telah disediakan pada lembar observasi proses supervisi kolaboratif. Untuk lebih jelasnya, Tabel 3. berikut adalah deskripsi hasil pengamatan peneliti sebagai observer:

Tabel 3. Deskripsi Hasil Observasi Proses Supervisi dengan Menerapkan Pendekatan Supervisi Kolaboratif pada Siklus 1

\begin{tabular}{cll}
\hline No & \multicolumn{1}{c}{ Tahapan Spesifik } & \multicolumn{1}{c}{ Temuan } \\
\hline 1 & Tahap Pra-Supervisi & Seluruh guru tidak membawa daftar masalah terkait \\
& Kolaboratif & kompetensi profesionalnya dalam mengembangkan materi \\
& & pembelajaran dan bahan ajar, curah pendapat dan diskusi \\
& & tidak berjalan dengan baik, hanya satu orang guru yaitu G05 \\
& yang aktif mencurahkan pendapatnya
\end{tabular}

\begin{tabular}{cll}
\hline 2 & $\begin{array}{l}\text { Tahap Pelaksanaan Supervisi } \\
\text { Kolaboratif }\end{array}$ & $\begin{array}{l}\text { Guru G03 dan G07 tidak menyiapkan hasil analisis materi } \\
\text { pembelajaran yang telah disusunnya sehingga mengganggu } \\
\text { proses supervisi kolaboratif }\end{array}$ \\
\hline 3 & $\begin{array}{l}\text { Tahap Pasca-Supervisi } \\
\text { Kolaboratif }\end{array}$ & $\begin{array}{l}\text { Seluruh guru terlibat dalam proses refleksi pelaksanaan } \\
\text { supervisi kolaboratif dengan menyampaikan temuan dan } \\
\text { pemecahannya }\end{array}$ \\
\hline
\end{tabular}

Pada siklus 1 ditemukan beberapa temuan pada tahap spesifik kegiatan supervisi kepala sekolah dengan menerapkan pendekatan supervisi kolaboratif. Hasil refleksi pada siklus 1 yang telah dilakukan menunjukkan beberapa hal sebagai berikut: (1) Seluruh guru tidak membawa daftar masalah terkait kompetensi profesionalnya dalam mengembangkan materi pembelajaran dan bahan ajar sehingga curah pendapat dan diskusi pada tahap Pra-Supervisi Kolaboratif tidak berjalan dengan baik dibuktikan dengan hanya satu orang guru berkode G05 yang aktif mencurahkan pendapatnya. Temuan ini diduga disebabkan oleh kepala sekolah yang tidak melakukan koordinasi dengan guru untuk mengidentifikasi masalahmasalah krusial pada saat melakukan kinerja profesionalnya dalam mengembangkan materi pembelajaran dan bahan ajar, mencatat dan membawanya pada saat curah pendapat dan diskusi dilakukan (tahap Pra-Supervisi Kolaboratif). Hal ini bertentangan dengan pendapat Glickman (1984) yang menyatakan bahwa tugas supervisi oleh kepala sekolah dalam supervisi kolaboratif adalah mendengarkan dan memperhatikan secara cermat keluhan guru terhadap masalah perbaikan, peningkatan, dan pengembangan kinerjanya. Dalam pendekatan supervisi kolaboratif, kepala sekolah dapat meminta penjelasan guru terhadap hal-hal yang kurang dipahaminya. Selanjutnya, kepala sekolah mendorong guru untuk mengaktualisasikan pemikiran bersama dalam praktik nyata pemecahan masalah yang berkaitan dengan tugas profesional guru. Dikarenakan pada tahapan ini guru tidak melakukan identifikasi masalah-masalah ketika melaksanakan kinerja profesionalnya dalam mengembangkan materi pembelajaran dan bahan ajar, tidak mencatat dan membawanya pada kegiatan pra-supervisi kolaboratif, sehingga bahan untuk diskusi dan curah pendapat sangat kurang dan tidak terfokus. Hal ini menyebabkan curah pendapat dan diskusi tidak dapat berjalan dengan baik, sehingga tahap Pra-Supervisi Kolaboratif tidak dapat dilaksanakan secara efektif. Adapun guru yang berkode G05 aktif mencurahkan pendapatnya tetapi masalah yang disampaikannya tidak terfokus pada kompetensi profesional terkait pengembangan materi pembelajaran dan bahan ajar. Berdasarkan hasil analisis data di atas, sebelum melakukan kegiatan supervisi kolaboratif khususnya pada tahap Pra-Supervisi Kolaboratif, kepala sekolah terlebih dahulu melakukan koordinasi dengan semua guru dan menjelaskan teknis supervisi kolaboratif yang akan dilaksanakan diantaranya 
mengindentifikasi masalah-masalah krusial ketika melaksanakan kinerja profesionalnya, mencatat dan membawanya pada saat curah pendapat dan diskusi bersama kepala sekolah dan guru lainnya. (2) Terdapat dua orang guru dengan kode G03 dan G07 yang tidak menyiapkan hasil analisis materi pembelajaran ketika supervisi kolaboratif dilakukan di sekolah sehingga pelaksanaan supervisi kolaboratif menjadi terganggu. Segiovanni (1987) menyatakan bahwa penilaian kinerja guru dalam mengembangkan materi pembelajaran dan bahan ajar tidak terlepas dari hasil analisis materi pembelajaran yang telah disusunnya. Menurutnya, menilai unjuk kerja guru dalam mengembangkan materi pembelajaran dan bahan ajar merupakan salah satu kegiatan yang tidak bisa dihindarkan dari prosesnya. Kegiatan penilaian kinerja guru dalam mengembangkan materi pembelajaran dan bahan ajar dilakukan terhadap hasil analisis materi pembelajaran yang sebelumnya harus disiapkan oleh guru sebelum melaksanakan kinerja profesionalnya dalam mengembangkan materi pembelajaran dan bahan ajar.

Berdasarkan hasil refleksi di atas, peneliti merekomendasikan pelaksanaan supervisi dengan menerapkan pendekatan supervisi kolaboratif untuk siklus 2 sebagai berikut: (1) Pada tahap PraSupervisi Kolaboratif, kepala sekolah harus terlebih dahulu melakukan koordinasi dengan semua guru dan menjelaskan teknis supervisi kolaboratif yang akan dilaksanakan diantaranya mengindentifikasi masalah-masalah krusial ketika melaksanakan kinerja profesionalnya, mencatat dan membawanya pada saat curah pendapat dan diskusi bersama kepala sekolah dan guru lainnya. (2) Pada tahap pelaksanaan Supervisi Kolaboratif, kepala sekolah harus menguatkan dan menegaskan kepada guru untuk menyiapkan kelengkapan untuk melaksanakan kinerja profesionalnya pada tahap pra-supervisi kolaboratif.

Supervisi kolaboratif pada siklus 2 ini dilaksanakan pada tanggal 10 s.d. 24 November 2019. Pendekatan supervisi kolaboratif pada siklus 2 dilaksanakan berdasarkan rekomendasirekomendasi pada siklus 1 dengan menerapkan kesepuluh prinsip pendekatan supervisi kolaboratif yaitu prinsip kolaboratif, kolegial, kemitraan, terbuka dan fleksibel melalui tahapan-tahapan spesifik sebagai berikut: (1) Tahap pra-supervisi kolaboratif, kepala sekolah terlebih dahulu melakukan koordinasi dengan semua guru dan menjelaskan teknis supervisi kolaboratif yang akan dilaksanakan diantaranya mengindentifikasi masalah-masalah krusial ketika melaksanakan kinerja profesionalnya dalam mengembangkan materi pembelajaran dan bahan ajar, mencatat dan membawanya pada saat curah pendapat dan diskusi bersama kepala sekolah dan guru lainnya. Selanjutnya, kepala sekolah bersama 8 gurumelaksanakan curah pendapat dan diskusi difasilitasi oleh kepala sekolah tentang masalahmasalah krusial yang teridentifikasi oleh guru dalam melaksanakan kinerja profesionalnya. Pada akhir tahap pra-supervisi kolaboratif, kepala sekolah menguatkan dan menegaskan kepada guru untuk menyiapkan kelengkapan diantaranya hasil analisis materi pembelajaran. (2) Tahap supervisi kolaboratif, kepala sekolah melaksanakan supervisi kolaboratif bersama guru pada saat guru lain sedang melaksanakan kinerja profesionalnya dengan menerapkan kelima prinsip pendekatan supervisi kolaboratif yaitu prinsip kolaboratif, kolegial, kemitraan, terbuka dan fleksibel. (3) Tahap pasca-supervisi, kepala sekolah bersama 8 gurumelaksanakan refleksi pelaksanaan kinerja profesional dan supervisi kolaboratif difasilitasi oleh kepala sekolah.

Temuan-temuan selama proses supervisi kolaboratif berlangsung dikumpulkan menggunakan lembar observasi proses supervisi kolaboratif dan catatan lapangan. Peneliti sebagai observer mengamati keterlaksanaan supervisi dengan menerapkan pendekatan supervisi kolaboratif yang selanjutnya memberikan deskripsi pada kolom yang telah disediakan pada lembar observasi proses supervisi kolaboratif. Untuk lebih jelasnya, Pada siklus 2 ini tidak ditemukan lagi temuan-temuan negatif, dan pelaksanaan supervisi kolaboratif sudah sesuai dengan tahapan-tahapan spesifik supervisi kolaboratif. Temuan-temuan positif pada tahap spesifik supervisi dengan menerapkan pendekatan supervisi kolaboratif. Hasil refleksi pada siklus 2 yang telah dilakukan menunjukkan beberapa hal sebagai berikut: (1) Curah pendapat dan diskusi berjalan dengan baik dan seluruh guru aktif berdiskusi dan mencurahkan pendapatnya dikarenakan pada tahap pra-supervisi kolaboratif, kepala sekolah terlebih dahulu melakukan koordinasi dengan semua guru dan menjelaskan teknis supervisi kolaboratif yang akan dilaksanakan diantaranya mengindentifikasi masalah-masalah krusial ketika melaksanakan kinerja profesionalnya, mencatat dan membawanya pada saat curah pendapat dan diskusi bersama kepala sekolah dan guru lainnya. (2) Pelaksanaan supervisi kolaboratif berjalan dengan efektif dan guru mampu menerapkan solusi-solusi dari masalah yang teridentifikasi sebelumnya sebagai hasil curah pendapat dan diskusi dengan guru lain dan kepala sekolah pada tahap prasupervisi kolaboratif. Hal ini dikarenakan bahwa proses supervisi kolaboratif telah menerapkan prinsip-prinsipnya yaitu kolaboratif, kolegial, 
kemitraan, terbuka dan fleksibel. Selain itu, Pada akhir tahap pra-supervisi kolaboratif, kepala sekolah menguatkan dan menegaskan kepada guru untuk menyiapkan kelengkapan dalam melaksanakan kinerja profesionalnya berupa hasil analisis materi pembelajaran. (3) Seluruh guru terlibat dalam proses refleksi pada tahap pascasupervisi kolaboratif dikarenakan kepala sekolah telah koordinatif dengan guru dan telah berhasil memotivasi guru untuk saling belajar.

Berdasarkan hasil refleksi di atas, peneliti merekomendasikan pelaksanaan supervisi dengan menerapkan pendekatan supervisi kolaboratif sebagai berikut: (1) Pada tahap pra-supervisi kolaboratif, kepala sekolah terlebih dahulu melakukan koordinasi dengan semua guru dan menjelaskan teknis supervisi kolaboratif yang akan dilaksanakan diantaranya mengindentifikasi masalah-masalah krusial ketika melaksanakan kinerja profesionalnya, mencatat dan membawanya pada saat curah pendapat dan diskusi bersama kepala sekolah dan guru lainnya. (2) Pada tahap supervisi kolaboratif, kepala sekolah harus menerapkan prinsip-prinsip pendekatan supervisi kolaboratif yaitu prinsip kolaboratif, kolegial, kemitraan, terbuka dan fleksibel. Serta untuk keberhasilan pelaksanaan kinerja profesionalnya, kepala sekolah harus menguatkan dan menegaskan kepada guru untuk menyiapkan kelengkapan berupa hasil analisis materi pembelajaran pada tahap pra-supervisi kolaboratif. (3) Pada tahap pasca-supervisi kolaboratif, kepala sekolah harus koordinatif dengan guru dan memotivasi guru untuk saling belajar. Berikut merupakan perkembangan temuan selama proses supervisi dengan menerapkan pendekatan supervisi kolaboratif dari siklus 1 ke siklus 2 .

\section{SIMPULAN DAN SARAN Simpulan}

Berdasarkan pembahasan dalam penelitian mengenai penerapan pendekatan supervisi kolaboratif untuk meningkatkan kompetensi profesional guru di SDN 14 Pulau Kumbang dapat ditarik beberapa simpulan sebagai berikut: (1) Proses supervisi dengan menerapkan pendekatan supervisi kolaboratif secara spesifik terdiri dari tahap pra-supervisi kolaboratif, supervisi kolaboratif dan pasca-supervisi kolaboratif. (2) Peningkatan kompetensi profesional guru di SDN 14 Pulau Kumbang dari pra-siklus ke siklus 1 sebesar 18,18 poin. Rata-rata kompetensi profesional guru pada pra-siklus sebesar 52,27 dengan kriteria kurang dan pada siklus 1 sebesar 70,45 dengan kriteria cukup. Kompetensi profesional guru juga mengalami peningkatan dari siklus 1 ke siklus 2 sebesar 18,19 poin.

\section{Saran}

Sebagai implikasi dari hasil penelitian, berikut ini dikemukakan rekomendasi yang diharapkan dapat memberikan sumbangan pemikiran dalam upaya meningkatkan kualitas supervisi oleh kepala sekolah, khususnya dalam menerapkan dan mengembangkan pendekatan supervisi kolaboratif. (1) Pada tahap pra-supervisi kolaboratif, kepala sekolah harus terlebih dahulu melakukan koordinasi dengan semua guru dan menjelaskan teknis supervisi kolaboratif yang akan dilaksanakan diantaranya mengindentifikasi masalah-masalah krusial ketika guru melaksanakan kinerja profesionalnya, mencatat dan membawanya pada saat curah pendapat dan diskusi bersama kepala sekolah dan guru lainnya. (2) Pada tahap supervisi kolaboratif, kepala sekolah harus menerapkan prinsip-prinsip pendekatan supervisi kolaboratif yaitu prinsip kolaboratif, kolegial, kemitraan, terbuka dan fleksibel. (3) Pada tahap pasca-supervisi kolaboratif, kepala sekolah harus koordinatif dengan guru dan memotivasi guru untuk saling belajar.

\section{DAFTAR RUJUKAN}

Alfonso, RJ., Firth, G.R., dan Neville, R.F.1981. Instructional Supervision, A Behavior System, Boston: Allyn and Bacon, Inc.

Ali Mohamad, 1987, Pengantar Statistik, Bandung.

Danim, Sudarwan. 2006. Visi Baru Manajemen Sekolah. Jakarta: Bumi Aksara.

Departemen Pendidikan dan Kebudayaan RI. 1982. Alat Penilaian Kemampuan Guru: Buku I. Jakarta: Proyek Pengembangan Pendidikan Guru.

1982. Panduan Umum Alat Penilaian Kemampuan Guru. Jakarta: Proyek Pengembangan Pendidikan Guru.

----------. 1996. Pedoman Kerja Pelaksanaan Supervisi, Jakarta: Depdikbud .1996. Jabatan Fungsional Kepala Sekolah dan Angka Kreditnya

Jakarta: Depdikbud. -1997. Pedoman Pembinaan

Profesional Guru Sekolah Dasar. Jakarta: Direktorat Pendidikan Dasar

--------. 1997. Pedoman Pengelolaan Gugus Sekolah: Jakarta: Proyek Peningkatan Mutu Sekolah Dasar, TK dan SLB

-----1998. Petunjuk Teknis Pelaksanaan Jabatan Fungsional Pengawas

Sekolah dan Angka Kreditnya, Jakarta: Depdikbud.

2003. Pedoman Supervisi Pengajaran. Jakarta: Ditjen Dikdasmen. 
Direktorat Tenaga Pendidik - Dirjen PMPTK Depdiknas RI, 2007, Supervisi Akademik dalam Peningkatan Profesionalisme Guru, Jakarta.

Direktorat Tenaga Pendidik - Dirjen PMPTK Depdiknas RI, 2008, Metode dan Teknik Supervisi, Jakarta.

Direktorat Pembinaan Pendidik dan Tenaga Kependidikan Pendidikan Dasar - Direktorat Jenderal Pendidikan Dasar Kementerian Pendidikan dan Kebudayaan, 2014, Supervisi Pembelajaran - Bahan Materi Bimbingan Teknis Penguatan Kepala Sekolah, Jakarta.

Glickman, C.D 1995. Supervision of Instruction. Boston: Allyn And Bacon Inc.

Gwynn, J.M. 1961. Theory and Practice of Supervision. New York: Dodd, Mead \& Company.
McPherson, R.B., Crowson, R.L., \& Pitner, N.J. 1986. Managing Uncertainty: Administrative Theory and Practice in Education. Columbus, Ohio: Charles E. Merrill Pub. Co.

Nolan, J.F. 2011. Teacher Supervision and Evaluation. Wiley: United State of America.

Oliva, Peter F. 1984. Supervision For Today's School. New York: Longman.

Peraturan Menteri Pendidikan Nasional No. 13 tahun 2007 tentang Standar Kompetensi Kepala Sekolah/Madrasah, Jakarta.

Peraturan Menteri Pendidikan Nasional No. 41 tahun 2007 tentang Standar Proses Jakarta.

Pidarta, Made. 1992. Pemikiran Tentang Supervisi Pendidikan. Jakarta: Bumi Aksara. 